\title{
南関東の下部更新 統
}

\section{多摩丘陵の三浦層群について——1}

\author{
関東第四紀研究会 ${ }^{2)}$ \\ Lower Pleistocene Formation in the Southern Kanto Region
}

\author{
Kanto Quaternary Research Group
}

\begin{abstract}
It is well known that the Plio-Pleistocene marine sediments in the Boso Peninsula, namely the Kazusa Group, are remarkably thick and continuous. Many investigations on the stratigraphy and the fossils contained within them have been made in detail. The age of the Kazusa Group has recently become clear by means of some biostratigraphic and geomagnetic works.

On the other hand, the Miura Group distributed over the Tama Hill adjacent to the Boso Peninsula has been poorly investigated. It was believed that the age of the Group was the Late Pliocene. In this paper, the writers described the stratigraphy and the geologic structure of the Miura Group in addition to the review of previous works on the Plio-Pleistocene formation in the Southern Kanto region. The results must offer some data on the restoration of the paleo-geography of this area.

(1) An indistinctive anticlinal structure was found about the upper reach of the Tsurumi River. It seems that the structure is based on the original sedimentary basin structure.

(2) The sedimentary facies of the Miura in the western region of the Tama Hill are characterized by the deposits of relatively shallow sea. In the lower part of the Miura, there are six sedimentary cycles due to the osillation of the sea level of the time.

(3) From some plant fossils, such as Metasequoia, Juglans, the age of the Miura is estimated to be the Early Pleistocene.
\end{abstract}

\section{I. は じめに}

関東地方，房総半鼻の上総層群は，鮮新世から更新世 にわたり，ほぼ連続的に堆積した厚い海成の地層群で， その発達がよいこと，軟体動物をはじめ，豊富な化石を 産することなどから，古くから多くの研究者の注目する ところとなっていた。近年になって，全国各地の鮮新一 更新統に関する資料も增し, 古地磁気の測定やフィッシ ョン・トラック法などの年代測定によって, 各地の鮮新 一更新統の対比が可能となりつつあり, 関東地方の上総 層群む，新らたな目で見直されるようになっている。

筆者らは，1967 年から 1969 年までの間に，上総層群
とならんで関東地方の鮮新一更新統として知られる, 多 摩丘陵三浦層群の調査をおこない，いくつかの新らしい 知見を得た。まだ，全体の地質構造，岩相分布などが明 らかにされた程度にとどまっており3，房総半島の上総 層群について明らかにされている諸事実の質, 量とは比 較にならないほど貧弱である.しかし，浅海堆積物とし ての三浦層群は，陸成層である近畿地方の大阪層群とい くつかの点で類似を示し, 堆積相からみて, 大阪層群 と, 半媣海堆積物である上総層群との, 中間的な性格を もつものということができる、「第四紀研究」本号の編 集委員会は，筆者らのグループに対し，上総層群に関す る問題の指摘を望んだが，三浦層群に関する問題の指摘

1) 一部は 1969 年地質学会講演, 一部は 1970 年第四紀学会講演.

2) 石井良治 (白鴎高), 大沢幸男 (上板橋三中), 岡重文 (地調), ${ }^{\circ}$ 加藤定男 (武藏丘高), 桂島茂 (地調) y ${ }^{\circ}$ 菊 地隆男 (都立大地理), 工藤周一 (ソニー学園), 小林修一 (石川島重工), 小森長轪 (武藏高); 杉山䭈 (大森 三小), 土屋竜雄 (小石川高), ○羽鳥謙三 (神代高), 府川宗雄 (町甲高), 堀越新 (蒲原小), 水上洋 (小平 三小), 村崎洋 (明星学園), 山岡進 (都立大学生), 渡辺亮二 (昭和高). ( ${ }^{\circ}$ 印執筆責任者). なお, 多摩丘陵 の団体研究注 3 次にわたっている. 1 次参加者 27 名, 2 次 29 名, 3 次 13 名. ここにかかげた名は 3 回 の団研のうち 2 回以上参加したものの氏名である,

3) 調査の詳報は稿を改めて行なう。 
は，上総層群のみならず，大阪層群とも無関係ではあり えないだろう、筆者らとしては, 上総層群に関する新資 料はもたないし, 従来の研究を概観するにとどめておく ことをおことわりしておく

報告の過程で次の方々にお世話になった，地質調查所 の三梨昂氏には，野外調査において指導をたまわった。 大阪市大の粉川昭平氏には, 植物化石の鑑定はじめ, 大 阪層群との対比についてもご教示をたまわった. 資源科 学研究所の柴崎達雄氏, 東洋大学工学部の新藤静夫氏, 消防研究所の細野義純氏, 国際航業の武田裕幸氏から は, 三浦層群の地質構造その他に関する有益なご意見を いただいた。記して厚くお礼申しあげたい。

\section{II. 関東南部の鮮新更新統研究概観}

房総半島の鮮新一更新統については，すでに戦前から 横山, 矢部, 野村, 植田, 槙山, 大塚, 池辺, 三土, 坂 倉など, 多くの研究者による層序, 化石, およびそれに もとづく気候変化の問題や，対比の問題を中心とする研 究があり，ほぼ，その全貌が明らかにされていた，戦後 になって, これらの研究を基礎に，小池清の遺稿とし て, 房総半島を中心とした南関東の地質構造発達史が, 系統的に明らかにされた（1957），小池によれば，古期 鮮新世の豊岡層群と新期鮮新世の関層群 (上総層群の下 半部にあたる) の間に，丹沢造山の継続としておこった 变動を示す黑滝不整合があり, 関層群は続く地殼の安定 期の積成盆地の沈降にともない堆積した, 半深海成堆積 物であるとのべられている.

戦後の研究は, 層序, 化石の研究はより精密になった こと，またそれにもとづく気候変化や対比，年代の問題 も,より精度の高いものとなった点で, 戦前の研究とは かなりのちがいがある.ひとつの研究の流れとして, 堆 積構造, 堆積機構の研究があげられよう. 小池 (1951) の他, 藤田・陶山 $(1952,1953)$ なぞの黑潼不整合をめ ぐる研究は学界の議論をよび, 藤田 (1953) により, 「地層の将棋倒し構造」のように堆積学の根本問題をふ くむ研究が，この地域をもとにおこなるれた。 また，三 梨ら（1959）により，上総層群の層序が詳細に示され， 火砕質鍵層による対比もより確実なものとなった（三梨 ら，1961）ばかりでなく, 平山・鈴木 (1968) は単層の 綿密な観察と追跡により, 堆積機構や環境を明らかにで きる展望を示した.ささらに, 石油関係の研究者によるボ ーリング資料にもとうくく総層群に関する研究も多く, 関東平野地下の地質構造が明らかにされてきた（河井， 1960 など).
戦後の研究のもう一つの流れは化石群集に関する研究 である. 浮遊性有孔虫, 軟体動物などの化石群集に関す る研究は，戦前にもおこなわれていたとはいえ，正確な 層序が確立されたととによってその意義が新たに生じて きた. 最近では，花粉，「超微化石」などの化石群集が これらに加えられている。こうした化石群集関する研 究は, 古水温, 古気候などの環境变化を明らかにするこ とばかりでなく，それと同時に鮮新一更新統境界問題を 新たに再燃させた.

浅野ら（房総研究グループ, 1957; 房総三浦研究グル 一プ，1958）注浮遊性有孔虫化石群集から上総層群の黑 滝, 黄和田, 大田代各層では暖海性群集が優勢だが，梅 ケ瀬層中部以上では寒流系群集に急変することを主張 し，このことから梅ケ瀬層中部に第 18 回万国地質学会 議の勧告にいう, 鮮新一更新統の境界があると考えた. また，生越（1959）洁，浅海成層でかつ寒流系種を含む 層準ということで，蓮見砂層（すなわち梅ヶ瀬層）のあ たりに更新統の下底があるとした，しかし，詳細な層序 をもと浮遊性有孔虫化石の分析をおこない, 細かい古 水温変化についてのべた青木（1964）によれば, 大田代 層上部, 梅ケ瀬層上部, 柿ノ木台層上部, 長南層, 笠森 層上部などの層準に寒流の影響がみとめられ，梅ケ瀬層 中部の「寒冷化」は必ずしも特徵的なものではないよう である・

一方, 新生代後期の古地磁気の变化にもとづく編年が 一般的になりつつあって, 中川ら (1969) は, 房総半島 の新生代層について地磁気編年を試みた結果, 鮮新一更 新世の境界（オルドヴフイ亜期中）は，ほぼ梅ケ瀬層中 部にあることを指摘した. 大西 (1969) は, 上総層群中 の花粉化石と大阪層群中の植物群との比較から, 境界問 題については中川らの結論を支持し, また, 上総層群の 植物群についても新たな資料を提供した。鮮新一更新統 境界問題は，結論だけをみれば以前とはかわりはない が，質的にはかなりちがっているといえよう。

以上のような綿密な生層序学的研究は, 単層の解析に よる堆積機構の研究, 古地磁気の研究ともあわせ, 古生 態学的な問題や, 磁場の逆転とも無関係でないようにみ える微化石の変異の問題などにも発展しつつある.

東京湾西岸の三浦半島北部の鮮新一更新統化関する研 究は, 房総半島の上総層群に関するそれらほど多くはな い.一般的な層序に関して, 大塚 (1937), 品田 (1959), 神奈川県（1955）などの報告がある.上総層群との対比 も試みられているが，多くは軟体動物や有孔虫などの化 石群集の比較にもとづくものであった. しかし，対比に 
関しては，三梨ら（1959）の綿密な火砕質鍵層の追跡に よって決定的なものとなったとみてよい，三梨らによれ ば, 房総半島の黄和田・大田代層が大船層に, 鮮新一更 新統とされた梅ケ瀬層は小柴層に, 国本・柿ノ木台層が ほぼ中里層に対比されることになる。

多摩斥陵の地質については，大塚（1932）によってま ず，生田，柿生付近を中心として層序がたてられた。 そ の後鈴木 (1934) により, 軟体動物化石, 德永 (1934) に より象化石 (Parastegoden aurorae), 島倉 (1935) によ り Juglans cinerea などが，大塚の「柿生層」から報告 された. Juglans cinerea は，大西 (1940)によって「平 山黄褐色砂層」(大塚，1932）少らも報告されている.

戦後, 德永ら (1949) により多摩丘陵三浦層群の全体 の層序がたてられ，記載された。また，寿円(1951， 1958，1661）の報告もあるが，それ德永らの層序をさ らに細分して, 連光寺互層の最下部の碑層および泥層 を, 三沢泥岩層として独立させ，この基底を不整合とし た点が主な相異点である。

\section{III. 多摩丘陵の地質}

多摩丘陵を構成する地層は，丘陵西部では砂を主とし た浅海堆積物，丘陵東部は泥を主とした相対的に深い相 の堆積物からなる.地質構造注丘陵西部では泳南北の 走向をもち，きわめてゆるい角度で東に傾いており，丘 陵東部では, 溝口から町田にかけて一つの向斜構造がみ とめられ，この向斜軸をこえた南東側では，湆ぼ東西の 走向にかわっている. 堆積相がやや深くなるのも，この 向斜軸を拈およその境界としている.

多摩丘陵の諸層は, とくに浅海性堆積物の場合岩相の 側方変化が大きい，丘陵北縁部をのぞいて一般に露出不 良のため, 従来の研究も調査者ごとに地層の追跡や層序 区分のしかたに多少の差があり，今回の筆者等の調査結 果は，それらともまた異なっている．今回の調査では以 上のような野外での問題があるために, 火砕質鍵層の追 跡を中心におこなったものである.その結果, 岩相の側 方変化や層厚の变化は，ょり一層明らかとなった，以 下，各層の記載を，露出の比較的よい丘陵北縁多摩川沿 岸地域を中心にのべることにする.なお，今回の報告で は，地層名は一応德永らの報告を踏墏した.これらの地 層名は，調査が完了した時点で再定義する予定である. (第 1 図, 第 2 図)。
大矢部泥岩屏、青灰色シルトないし砂質粘土からな る、八王子市原東大矢部より西方に分布する。多摩丘陵 西端の八王子市館町付近の谷沿いに，基盤の小仏層に， 不整合に，角砅を主とする基底礫岩をともなって重なる のがみとめられる。

平山砂層. 丘陵北縁での 層厚約 $50 \mathrm{~m}$. 八王子市平山 付近から, 野猿峠, 御殿峠付近に分布し, 御殿峠碩層の 基盤をつくっている. 淘汰のよい細粒砂ないし粗粒砂か らなり,クロスラミナが発達する.徳永ら（1949）によ り平山北方平山橋下ょり多量の軟体動物化石, 有孔虫化 石が報告されている.

連光寺互㾍. 層厚約 $110 \mathrm{~m}$. 碴, 泥扔よび砂の互層か らなり，泥質部にはしばしば特幑的な凝灰岩りをはさむ ので, 鍵層として利用される. 丘陵北縁部では, 礫一泥 一砂という堆積のサイクルが $\mathbf{5}$ 層準に夕とめられるが, 南方に層相は変化し, 町田市小野路付近では細䃯まじり の黄褐色の中粒層砂を主とし, 植物片を含む砂質泥層を はさむようになったり，さらに鶴見川北岸では黄色の中 粒ないし細粒砂層, 南岸では砂泥互層へとかわる. 従 来, 小野路付近の砂層は稲城砂層, 鶴見川以南の砂泥互 層法鶴川互層とされていたのだが，凝灰岩の追跡によ り，上記のような層相変化が明らかにされたわけであ る.

走向はほぼ南北，東に $2 / 100$ ないし $2.5 / 100$ のゆる い傾斜を示寸. 泥層中には植物化石を多産し, オオバタ グルミ，メタセコイアその他をふくむ2．

なお, 德永ら（1949）に上れば本層の最下部は日野町 三沢の泥岩層とされ，前述のように寿円 (1951) はこれ を独立させて三沢泥岩層とし，その基底を不整合とした (寿円・原田, 1961) 3). しかし，三沢泥岩層の基底の 䃯層の下底には侵食のあとはみられるが，これを不整合 とする理由はないむしろこの䃯層は側方に尖滅するこ とや, 三沢泥岩層の下位にはもう一つの䃯一泥一砂のサ イクルが認められることなどから，平山砂層と連光寺互 層は整合とみるのが妥当であらう。

啝城砂屈. 層厚約 $190 \mathrm{~m}$. 細かい内磷ををれにふくむ 淘汰のよい灰黄色ないし黄褐色の中粒砂を主とする。う すい泥層をはさむことがある.多摩丘陵北縁では，西方 の連光寺から 東方の生田の 読売ランド付近にまで 分布 する. 三沢川沿いの本層のほぼ中位にあたるところに， 連光寺互層中にあったような硆一泥一砂のサイクルが 1

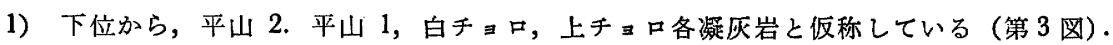

2）粉川昭平氏の私信によれば, 近畿地方の大阪層群下部のフロラと似ているという。

3）成瀬（1968）も福田・石和田（1964）にもとづいて不整合と考えている,
} 

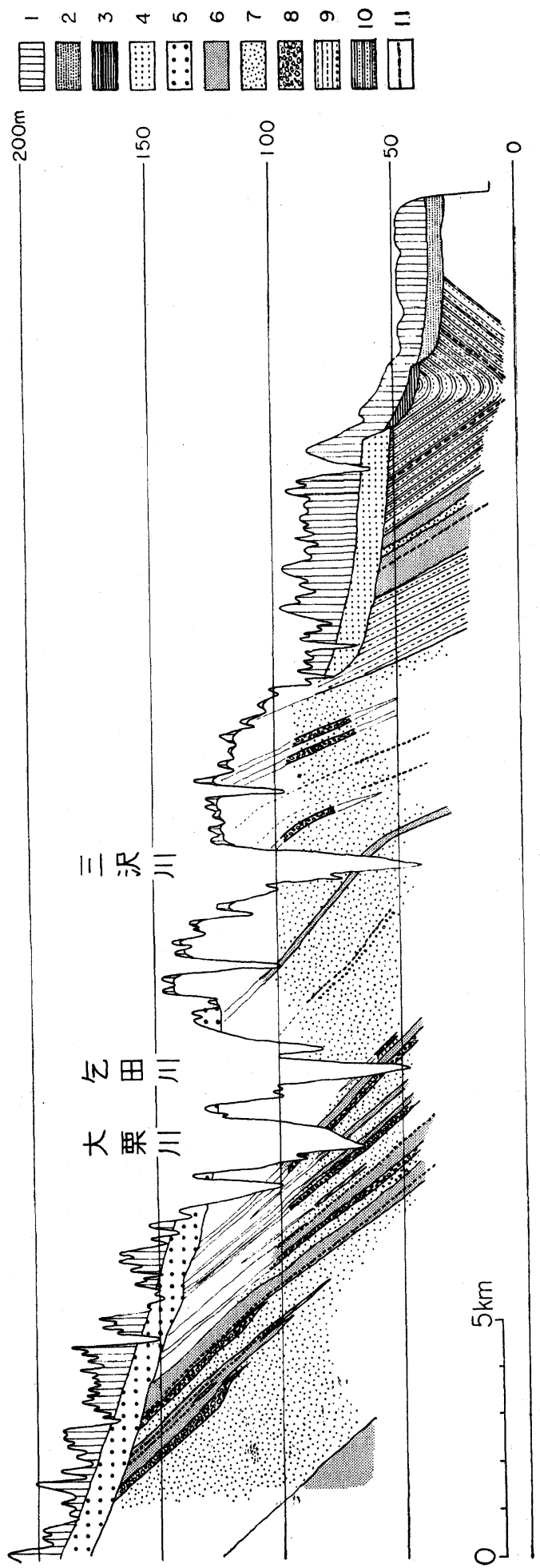

つタとめられる．また本層の上半部は泥（百村付近） や䃯（読売ランド付近）がはさまれるようになり， 徳永ら（1949）により鶴川互層にされ，また，寿円 酋（1958）により, 鶴川互層, 奈良泥岩層, 平尾砂 迹層, 根方凝灰質砂層, 王禅寺互層, 出店砂磞層なぞ に分けられている．丘陵内部では多摩町分生，町田 市広袷等に本層の分布がみられる. 南方㳄次第に泥 質層に移化し，下半部は鶴川互層と上半部は柿生泥 層と指交する関係比ある. 本層の上半部に汹火砕質 鍵層1 ${ }^{11}$ が多く，南方への追跡が可能である.

地質構造は三沢川より西方で $2 / 100$, 東方で $5 / 100$ (約 $3^{\circ}$ ) で東に傾く. 走向は西方でほぼ南北, 東 にゅくにつれ次第に NE-SW の方向に向きがかわ るようになる。

堆川互層. 本層の模式地である町田市下大蔵付近 （德永ら，1949）では，層理面の不明瞭な細砂と砂 質粘土の細互層で，このような岩相は，小田急線沿 いに鶴川から玉川学園付近一带にみとめられる. 町 田市北部の薬師池から西方では, 砂・シルトの厚互 層になっている，下限汇露出が悪いことと，丘陵の 南西側法境川により限られているために不明であ る. 上位は鶴川の東で柿生泥層に整合におおわれ る. 鶴見川をはさえで北の方に分布する連光寺互 層, 稲城砂層とは，横に移りかわる関係にあること は，すでにのべた通りである。

本愿の分布域は，ほ添鶴見川の南側にあたってい るが,この付近の地質構造をみると, 走向は $\mathrm{N} 10^{\circ} \mathrm{E}$

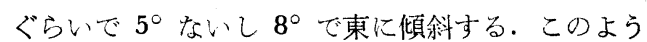
な構造から鶴見川沿いに不明瞭な形でドーム状の構 造が存在することが考えられる. 詳しくは後述す る.

柿生泥屏. 小田急線沿いの柿生, 百合ヶ丘付近お よび南方の亀井，奈良町付近江分布する．無層理の シルトないしシルト質細砂からなり，径 $2 \mathrm{~mm}$ 大 の軽石粒が点在し，数枚の特徵的な凝灰岩層を含 む. 層厚約 $100 \mathrm{~m}$. 奈良町付近の塊状シル卜層は, 徳永ら（1949）により奈良泥岩層とされているが， 火砕質鍵層の追跡から，本層の連続とみられる。

生田砂層－丘陵北縁で注川猗市生田付近から稲目 付近に分布する細砂と砂質粘土からなる不明暸な互 層で，層相は鶴川互層と似ている，層厚約 $100 \mathrm{~m}$.

1）下位から，黑川，根方，百合ケ丘 2 , 百合ケ丘 1, 本ゴマ各凝灰岩と仮称している(第 3 図)。 


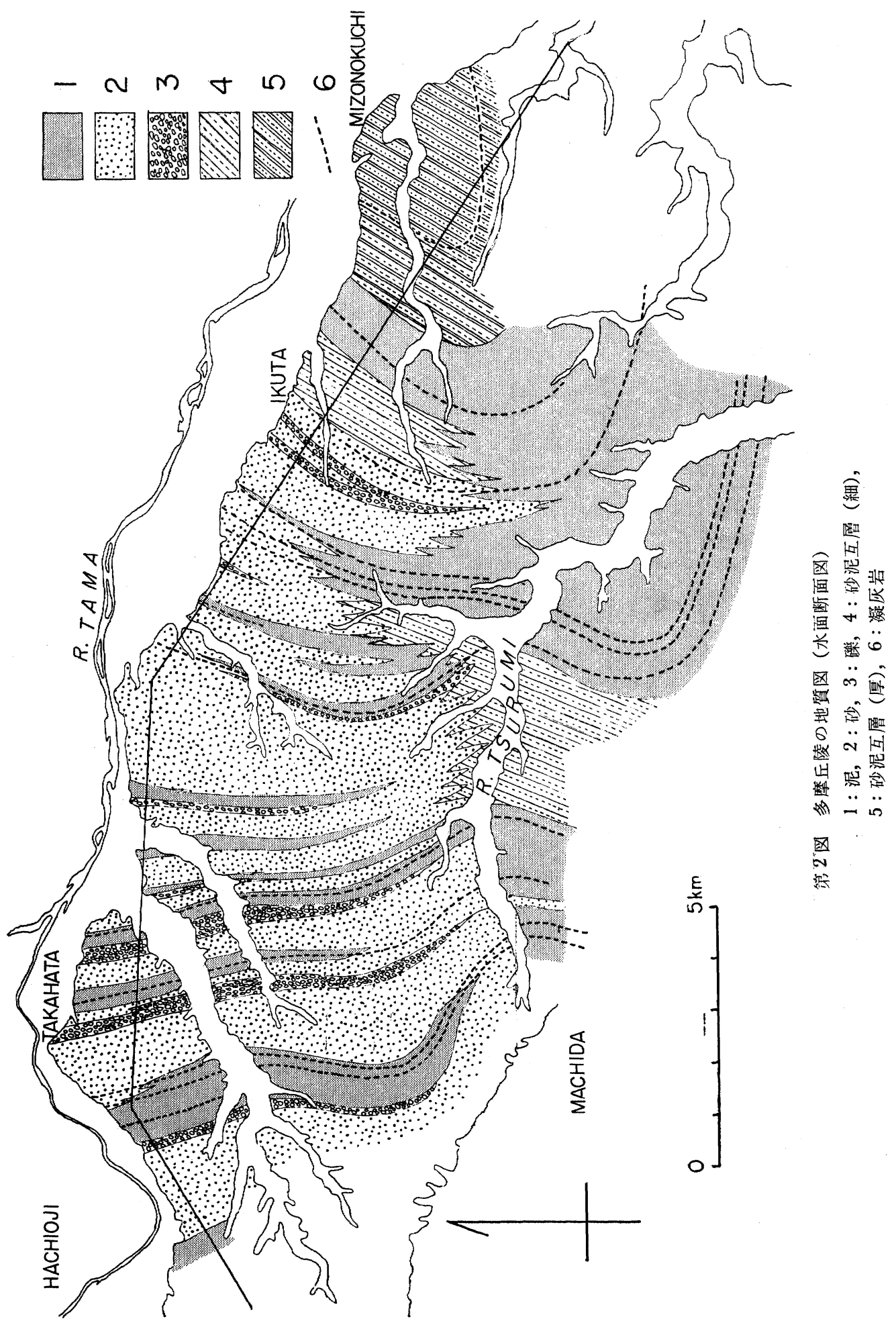




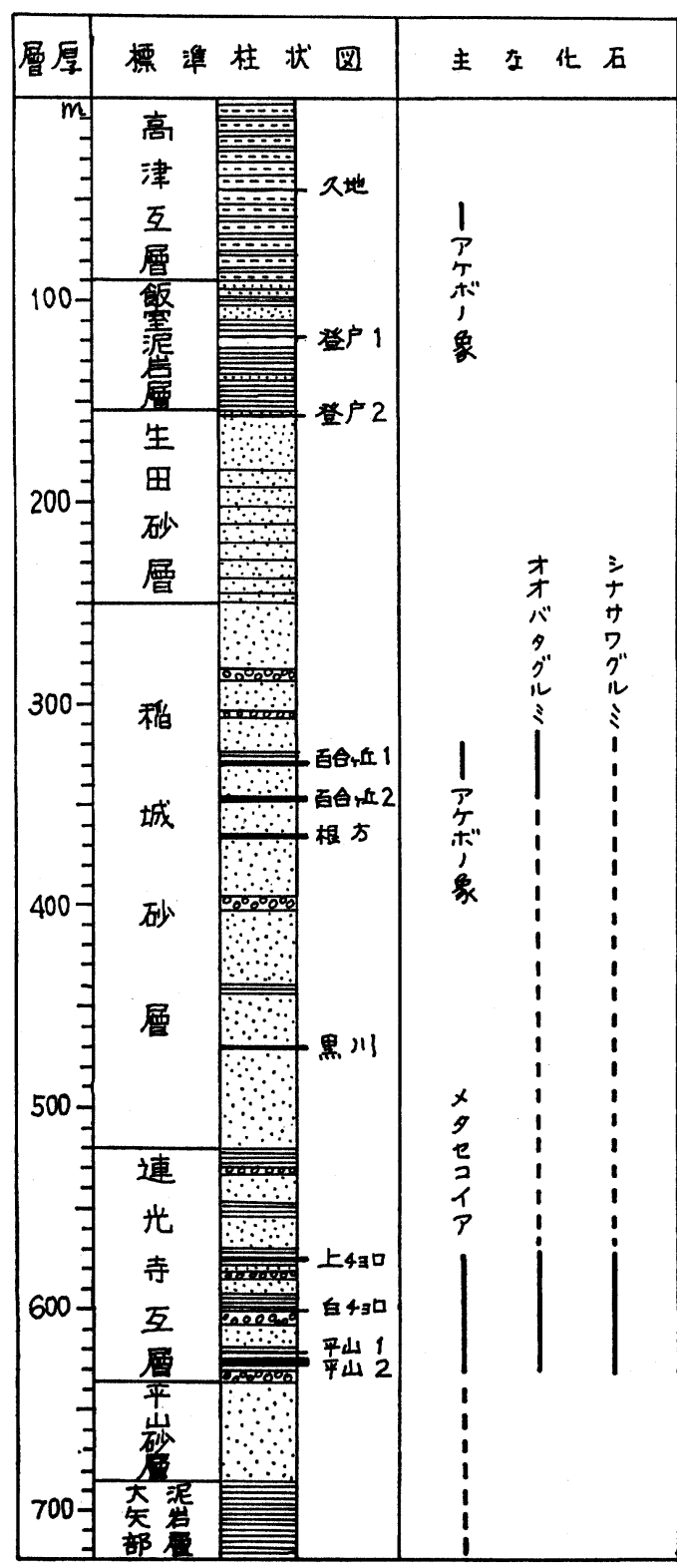

第 3 図多摩川沿岸における三浦層群の標準柱状困

走向はほぼ $\mathrm{N} 45^{\circ} \mathrm{E}$ で，南東に約 $2^{\circ}$ で傾むく.

飯宔泥岩虽. 層厚約 $60 \mathrm{~m}$. 軟体動物化石や軽石粒を 点在させる塊状の灰色シルト岩からなる，ときに砂層を はさむこともある．岩相は柿生泥層に似ている，丘陵北 縁では，向ガ丘遊園から宿河原付近に分布している.

高津互属. 層厚 $90 \mathrm{~m}$ 以上. シルトと細粒砂の互層か らなる.川崎市久地，溝口，新作付近に分布し，多摩丘
陵三浦層群の最上部層である。なお, 地質調査所地質部 (1958) によって川崎市新作から Parastegodon cf. aurorae が発堀されている.

\section{IV 三浦層群に関する問題点}

筆者らの今回の調査では, とくに地質構造, 層相変化 などの点で, 従来とは若干異なる結果を得た。ここにあ らためて下部更新統としての三浦層群の地質学的問題点 を整理し，考察を加えておきたい。

（1）町田一溝口に認められていた溝口向斜の他に， 鶴見川上流部にあたる淵野辺から東方の鶴川にかけて， 1 つの不明瞭な背斜構造が認められた. これを淵野辺背 斜と呼ぶことにする. 淵野辺背斜の構造をみると，北翼 の走向傾斜はほぼ N20W，2E であるが，南翼の走向傾 斜はほぼ N 10E，7Eという形を示している. 背斜軸の 北東方の延長は，丘陵北縁の稲城町根方の方向にのびる ようにみえる.ここでは構造はやや不明暸となって，三 浦層群の傾斜がこの付近でやや急になっているという程 度のものである.

（2）三浦層群の厚さの分布を概略的にみると，溝口 向斜の南翼より北翼の方が厚くまたより浅海相である. 一方, 淵野辺背斜の北翼と南翼でも, 層厚および層相と もに異なっている. 北翼では鿬まじりの砂層（連光寺互 層）であるのに，南翼は砂泥互層（鶴川互層）となり， 厚さも 2 倍以上厚くなる.このことは, 溝口向斜や淵野 辺背斜が単純な構造ではなく, 堆積当時の古海底地形を 表現しているものと思われる. 第4 図にその概念図を示 す.

（3）三浦層群の層相は，当然のことながら多摩丘陵 北西部の基盤山地に近い方が, 砅, 砂, 泥など岩相变化 がいちじるしく，植物遺体などを多くふくみ，軟体動物 化石も浅海, 内湾性のものが多い. また, 丘陵東部, 南 部の地域は, 塊状のシルト層や, 砂・泥互層などで示さ れ，外洋性の軟体動物化石をふくえでいる.

（4）丘陵西部に分布する浅海相を示す連光寺互層の 中には, 䃯一泥一砂の堆積のサイクルが 5 つの層準に認 められ，また，稲域砂層中にも 1 つ認められる.これら は, あるいは堆積当時の海水準変動の影響を示すものか も知れない.

（5）三浦層群中の植物化石からみて，三浦層群は， 近畿地方の大阪層群と対比することができる. 三浦層群 はまた，三梨ら（1958）によって火砕質鍵層にもとづき 房総半島の上総層群と対比されているが，そのことと矛 盾しない. 


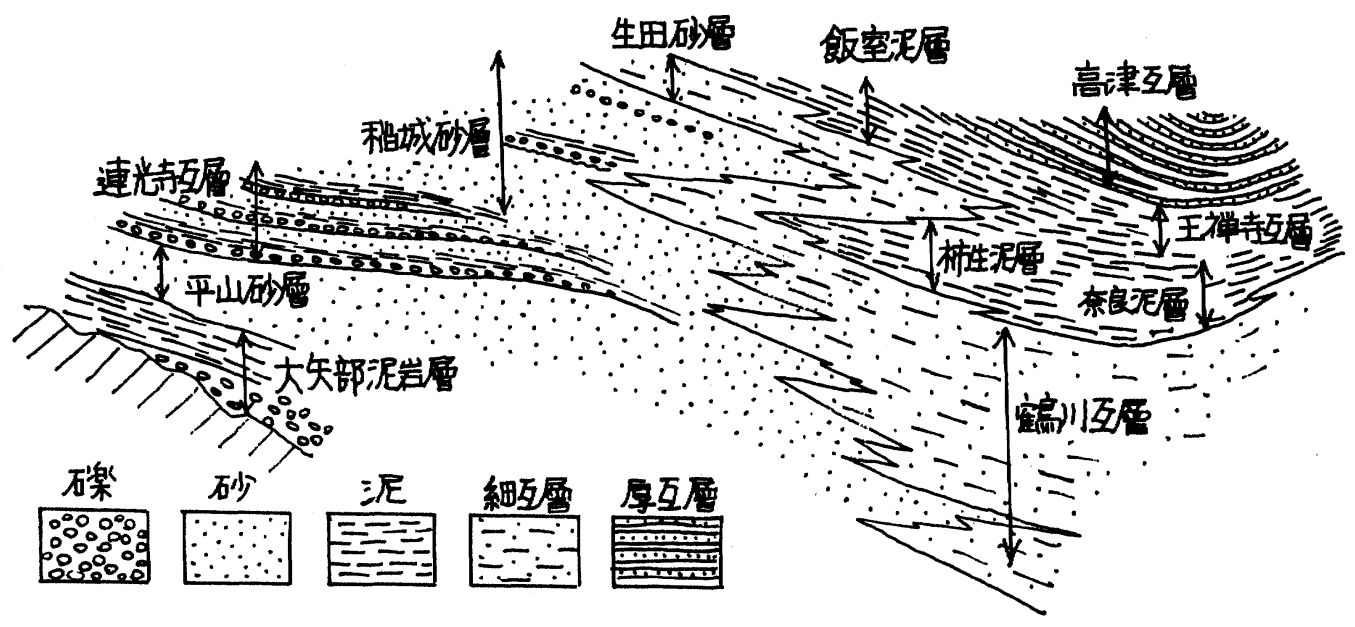

第 4 図 三浦層群の層相变化を示す概念図

（6）多摩丘陵三浦層群の北方への延長, とくに加住 丘陵, 草花丘陵, 狭山丘陵1), 阿須山丘陵などの諸丘陵 の地層群，および南西方とくに中津累層などとの関係は 未解決になっている. これらの諸層との関係, そして各 層中に含まれる微化石群集の詳細な分析がおこなわれれ ば, 関東平野西縁地域の前期更新世の古地理の变遷を, より正確にえがくことも可能であろう.

\section{交献}

青木直昭 (1964) 房総半島の鮮新世一更新世浮遊性有孔 虫化石群. 地質雑, 70, 170 179.

房総研究グループ (1957) 房総半島新生代地層群の地史 区分. 有孔虫, (7), 32〜37

房総・三浦研究グループ (1958) 房総半島並に三浦半島 新生代地層群の浮遊性有孔虫化石による 対比. 有孔 虫, (9), 34〜39.

地質調查所地質部（1958）地質調査所付近で発堀された 象歯化石，地質二ュース，45.

藤田至則 (1953) 地層の将棋倒し構造について. 新生代 の研究, 18, $1 \sim 10$.

藤田至則 - 陶山国男 (1952 - 1953) 小檟川 - 養老川上流 地域の中部鮮新統の 堆積機構 (その一), (その二). 地質雑，58，553〜 561，59，25〜31.

福田理・石和田靖章 (1964) 関東地方の地質と天然ガス 鉱床の探鉱之開発への序章. 石油技協誌，29，4２1.

平山次郎・鈴木尉元 (1968) 単層の解析—その実際と 堆積学的意義について——. 地球科学, 22, 43〜 62.

寿円晋吾 (1951) 多摩丘陵の地形学的研究——特に開折 単位と小分岐丘陵両翼の非対称性について—. 地理 評, 24, 391 403.

寿円晋吾 (1958) 多摩丘陵の地形と地質. 波丘地農業研
究所報, 1, 27〜 45.

寿円晋吾 - 原田静男 (1961) 波丘地試験地の地下水探 查. 波丘地農業研究所報, 3, 50 56.

神奈川県 (1955) 神奈川県下の天然ガス地下資源. 神奈 川県総合開発計画資料, 8 .

河井興三 (1960) 南関東ガス田地帯における天然ガスの 分布について. 石油学会誌, 3, 213〜218.

小池 清（1951）いわゆる黒滝不整合について.地質雑, 57, 143〜 156 .

小池 清 (1957) 南関東の地質構造発達史. 地球科学, (34), 1 16.

三梨 昂・安国 昇・品田芳二郎（1959）千葉県養老川 - 小櫝川の上総層群の層序一養老川 - 小櫃川流域地 質調查報告——. 地調月報， 10，83 98.

三梨 昂・矢崎清貫 (1958) 火砕岩鍵層による房総・三 浦両半島の 新生代層の対比（第 1 報). 石油技協誌, 23, 16 22.

三梨 昂 - 矢崎清貫 - 影山邦夫 - 島田忠夫 - 小野 暎 · 安国 昇・牧野登喜男・品田芳二郎・藤原清丸・鎌田 清吉（1961）日本油田・ガス田図 4, 富津一大多喜. 地質調査所.

中川久夫 · 新妻信明 - 早坂 功 (1969) 房総半島新生代 地磁気編年. 地質雑, 75, 267 280.

成瀬 洋 (1968) 南関東における Plio-Pleistocene 境界 ごろの地壳変動. 第四紀, (12), 63〜67.

生越 忠 (1959) 軟体動物化石からみた房総半島におけ る鮮新一更新両世の境界について. 地質雑, 65, 139 153.

大西 弘 (1940) 東京府八王子市近傍産化石 2 種バタグ ルミ (Juglans cinerea) とエゾシカ (Cervus cf. yessoensis). 地質雑, 47, 78〜80.

大西郁夫 (1969) 房総半島・上総層群の花粉フロラ. 地

1）最近屏風ガ浦層に対比されていた狭山層から Metasequoia その他の植物化石が発見され, 三浦層群と対比され ることがあきらかとなった（埼玉日曜巡検会・関東第四紀研究会，1970）. 
球科学, 23, 236 242,

大塚弥之助 (1932) 多摩丘陵の地質 (其の 1). 地質雑, 39, $641 \sim 655$.

大塚弥之助 (1937) 関東地方南部の地質構造「横浜一藤 沢間」. 震研啋報, 15, 974 1040.

埼玉日曜巡検会・関東第四紀研究会 (1970) 狭山丘陵办 ら Metasequoia flora の発見. 地質雑, 76, 315-316.

舄倉己三郎 (1935) 神奈川県下に産する Juglans cinerea L. の化石. 地質雑, 42, 45〜47.
品田芳二郎（1959） 神奈川県大船附 近天然ガス 調查報 告. 地調月報, $10,531 \sim 535$.

鈴木好一 (1934) 柿生層の化石群 (I. 貝類). 地質雑, 41, $701 \sim 712$.

德永重康（1934）横浜市及び神奈川県柿生村発見の象歯 化石について. 地学雑, 46, 363 371.

德永重元 · 郷原保真 · 桑野幸夫 (1949) 多摩丘陵の地 質. 資源研彙報， (14)，43〜60. 